\title{
The effects of applied water at various fractions of measured evapotranspiration on water relations and vegetative growth of Thompson Seedless grapevines
}

\author{
L. E. Williams $\cdot$ D. W. Grimes $\cdot$ C. J. Phene
}

Received: 2 March 2009/ Accepted: 27 July 2009/Published online: 1 September 2009

(C) The Author(s) 2009. This article is published with open access at Springerlink.com

\begin{abstract}
Vegetative growth and water relations of Thompson Seedless grapevines in response to applied water amounts at various fractions of measured grapevine $\mathrm{ET}_{\mathrm{c}}$ were quantified. Treatments ranged from no applied water up to 1.4 times the water used by vines growing in a weighing lysimeter. All treatments were irrigated at the same frequency as the vines in the lysimeter (whenever they used $2 \mathrm{~mm}$ of water), albeit at their respective fraction. Soil water content and midday leaf water potential $\left(\Psi_{1}\right)$ were measured routinely in four of the irrigation treatments across years. The amount of water depleted in the soil profile ranged from $190 \mathrm{~mm}$ for the 0.2 treatment in 1993 to no water depletion for the 1.4 treatment in 1992. The irrigation treatments significantly affected midday $\Psi_{1}$, total shoot length, leaf area per vine, pruning weights and trunk diameter; as applied water decreased so did vegetative growth. Pruning weights were a linear function of the seasonal, mean midday $\Psi_{1}$ across growing seasons. The
\end{abstract}

Communicated by E. Fereres.

L. E. Williams $(\square)$

Department of Viticulture and Enology,

University of California, Davis, CA, USA

e-mail: williams@uckac.edu

D. W. Grimes

Department of Land, Air and Water Resources,

University of California, Davis, CA, USA

L. E. Williams · D. W. Grimes

Kearney Agricultural Center, 9240 S. Riverbend Ave.,

Parlier, CA 93648, USA

C. J. Phene

Water Management Research Laboratory,

USDA-ARS, Parlier, CA 93648, USA application of water amounts in excess of evapotranspiration negatively affected vegetative growth some of the years. A companion paper will demonstrate that over-irrigation can negatively affect reproductive growth of this grape cultivar due to excess vegetative growth.

\section{Introduction}

The competition among agricultural, societal and environmental interests for limited water supplies is increasing and this competition can be exacerbated in years where annual rainfall is below normal throughout the state of California and at other locations around the world (Laraus 2004; Morison et al. 2008). These circumstances require that agriculture becomes more efficient in the use of this natural resource (Morison et al. 2008). Increasing water use efficiency by agriculture can span various scales, going from individual farms to watersheds to regions and involve various disciplines including hydrology, engineering and soil and plant sciences (Hsiao et al. 2007). Future increases in water use efficiency at the farm level will require a more scientific basis for irrigation scheduling to include: (a) better estimates of crop water use, (b) yield response to applied water amounts or crop evapotranspiration and (c) a means to determine the timing of an irrigation event and/or assessing the level of plant stress (Fereres and Evans 2006).

Crop evapotranspiration $\left(\mathrm{ET}_{\mathrm{c}}\right)$ can be estimated using reference evapotranspiration $\left(\mathrm{ET}_{\mathrm{o}}\right)$ and reliable crop coefficients (Allen et al. 1998). Grapevine $\mathrm{ET}_{\mathrm{c}}$ of Thompson Seedless has been determined with the use of a weighing lysimeter (Williams et al. 2003a) and seasonal crop coefficients developed for vines during the first 7 years of development (Williams and Ayars 2005a; Williams et al. 
2003b). In addition, it was shown that grapevine $\mathrm{ET}_{\mathrm{c}}$ and the crop coefficient are a linear function of the amount of shade cast on the ground at solar noon (Williams and Ayars $2005 \mathrm{~b}$ ). A similar type of relationship ( $K_{\mathrm{c}}$ as a function of the amount of light intercepted by the canopy at midday) has been established for peach trees (Prunus persica (L.) Batsch) (Ayars et al. 2003). The relationship between the $K_{\mathrm{c}}$ and shaded area beneath grapevines has been used to schedule irrigation amounts at different locations in California (Williams and Baeza 2007). Therefore, more reliable estimates of grapevine water use in California can be obtained using the above information and should assist in using scientific means to schedule irrigations (Fereres and Evans 2006).

Plant and soil based methods to assess crop water status and their relationships with one another are needed to assist in irrigation scheduling (Jones 2004). It has been demonstrated that leaf $\left(\Psi_{1}\right)$ and stem $\left(\Psi_{\text {stem }}\right)$ water potentials of grapevines are highly correlated with one another (Intrigliolo et al. 2005; Stevens et al. 1995; Williams and Araujo 2002; Williams and Trout 2005). A fully irrigated baseline, using either $\Psi_{1}$ or $\Psi_{\text {stem }}$ as a function of vapor pressure deficit at the time of measurement, was recently developed for grapevines (Williams and Baeza 2007). Leaf and stem $\Psi$ s of grapevines are also highly correlated with soil water content (SWC) and soil matric potential and measures of leaf gas exchange (Williams and Araujo 2002; Williams and Trout 2005). Seasonal values of midday stomatal conductance and $\Psi_{1}$ and crop water stress index (CWSI) have been shown to be highly correlated with Thompson Seedless yield (Grimes and Williams 1990). Therefore, there are numerous vine and soil based methods one can use to assist in developing a scientifically based vineyard irrigation management program in California.

A weighing lysimeter was installed at the Kearney Agricultural Center in 1987, planted with Thompson Seedless grapevines and seasonal $\mathrm{ET}_{\mathrm{c}}$ measured and crop coefficients calculated (Williams and Ayars 2005a; Williams et al. 2003b). Subsequent to vine training (3 years after planting) irrigation treatments were established in the vineyard surrounding the lysimeter consisting of applied water amounts at various fractions $(0,0.2,0.4$, $0.6,0.8,1.0,1.2$ and 1.4) of measured lysimeter water use. This allowed us to determine the responses of vegetative and reproductive growth of Thompson Seedless vines to both under- and over-irrigation and then relate these responses to $\mathrm{ET}_{\mathrm{c}}$ and the $K_{\mathrm{c}}$. This paper describes the effects of these treatments on SWC, vine water status, grapevine phenology and vegetative growth, the former parameters with potential for use in a vineyard irrigation management program (Jones 2004). A companion paper describes the effects of these treatments on reproductive growth and water productivity of the same Thompson Seedless grapevines (Williams et al. 2009).

\section{Materials and methods}

The vineyard used in this study was planted on 9 April 1987 with cuttings of Vitis vinifera L (cv. 'Thompson Seedless' clone 2A) at the University of California Kearney Agricultural Center located in the San Joaquin Valley of California $\left(36^{\circ} 48^{\prime} \mathrm{N}\right.$, lat, $119^{\circ} 30^{\prime} \mathrm{W}$, long.). Vine and row spacings were 2.15 and $3.51 \mathrm{~m}$, respectively $\left(7.55 \mathrm{~m}^{2}\right.$ per vine). Row direction was $6^{\circ}$ north of the east/west axis. The vineyard was approximately 1.4 ha $(168 \times 82 \mathrm{~m})$. The soil was a Hanford fine sandy loam (coarse-loamy, mixed, nonacid, thermic Typic Xerorthent). Three trellis systems were used in the study: (1) A single wire placed atop a $2.13 \mathrm{~m}$ wooden stake driven $0.45 \mathrm{~m}$ into the soil at each vine, (2) A $0.6 \mathrm{~m}$ cross-arm placed atop the stake and wires attached at either end of the cross-arm to support the vine's fruiting canes and (3) A 1.2 m cross-arm placed atop the stake and wires attached at either end of the cross-arm to support the shoots and another two wires attached $0.3 \mathrm{~m}$ from the stake to support the fruiting canes. The vines were cane-pruned during the dormant portion of the growing season with each cane approximately $12-15$ nodes in length. The numbers of canes per vine left after pruning were 4, 6, 8 and 8 in 1990, 1991, 1992 and 1993, respectively. The canes were then wrapped around the fruiting cane wires on each of the trellises. Cultural practices to control diseases and insect pests were performed by field station personnel as described previously (Williams et al. 2003b; Daane and Williams 2003).

The vineyard also contained a weighing lysimeter in which two grapevines were planted at the same time the rest of the vineyard was planted. The trellis system for the two, lysimeter vines consisted of a $0.6 \mathrm{~m}$ cross-arm, similar to that described above. The operation of the lysimeter and other technical details can be found in Williams et al. (2003a, b). Vines within the lysimeter and the surrounding vineyard were irrigated with $4 \mathrm{~L} \mathrm{~h}^{-1}$ in-line drip emitters, spaced every $0.30 \mathrm{~m}$ in the vine row. The drip tubing was attached to a wire suspended $0.4 \mathrm{~m}$ above the soil surface. The lysimeter was weighed hourly to determine ET of the two vines and when the decrease in weight exceeded an equivalent of $16 \mathrm{~L}\left(8 \mathrm{~L} \mathrm{vine}^{-1}\right)$ threshold value the lysimeter was irrigated. The number of irrigations per day throughout each growing-season ranged from 0 to 7 .

The irrigation pump for the rest of the vineyard was controlled by the lysimeter's datalogger (Campbell Scientific, 21X Micrologger). Whenever the lysimeter was irrigated the vineyard pump was activated and an irrigation event took place. The irrigation treatments were applied 
water amounts at various fractions $(0.2,0.4,0.6,0.8,1.0$, 1.2 and 1.4) of lysimeter water use. The irrigation treatments supplied with water amounts less than $\mathrm{ET}_{\mathrm{c}}$ season long, as done in this study, have been termed 'sustained deficit irrigation' or 'SDI' (Fereres and Soriano 2007). A non-irrigated treatment was also included. The irrigation treatments were first imposed during the 1989 growing season. No supplemental irrigation water was applied during the dormant portion of the growing season regardless the amount of rain that fell prior to budbreak each year. Irrigation treatments within each of the 8 blocks of the experiment were set up in a line-source design, proceeding sequentially from the lowest to highest amount, the direction within each block randomly assigned. Two rows separated each block and the border row irrigated with the amount of water given the irrigation treatment assigned to the outside data row of the respective block. Each irrigation treatment plot consisted of 18 vines down a single row. Within each irrigation plot, the three trellises described above were installed using six vines per trellis sub-plot. The activation of solenoid valves at the head of each row for various times was used to provide the differing fractions of applied water. In-line water meters upstream from the solenoid valves in each row measured actual applied water amounts. The water meters were initially calibrated in 1989 and again before the 1992-growing season. Both times all meters were within $3 \%$ of the measured amounts.

The volumetric SWC in the 0.2, 0.6, 1.0 and 1.4 irrigation treatments was monitored using the neutron backscattering technique with a neutron moisture probe (Model 503 DR Hydroprobe Moisture Gauge, Campbell Pacific Nuclear, Martinez, CA, USA). Nine access tubes were placed in one quarter of an individual vine's rooting volume and inserted to a depth of $3 \mathrm{~m}$. Three access tubes were placed down the vine row (directly below the drip line), one close to the trunk, one midway between vines within the row and the third midway between the two previously mentioned tubes. Another three tubes were placed midway between rows, perpendicular to each of the three tubes placed within the row. The last three tubes were placed midway between the former two sets of tubes. Readings were taken at a depth of 0.23 and $0.45 \mathrm{~m}$ beneath the soil surface and then in increments of $0.3 \mathrm{~m}$ down to a depth of $2.90 \mathrm{~m}$. Each access tube site was replicated three times, in three of the eight blocks, for each irrigation treatment mentioned previously. The neutron probe was calibrated according to Araujo et al. (1995) and SWC values expressed as percent by volume $\left(\theta_{\mathrm{v}}\right)$. The SWC content at field capacity of this soil type was approximately $22.0 \%$ by volume while SWC at a soil moisture tension of $-1.5 \mathrm{MPa}$ was approximately $8.0 \%$ by volume. Therefore, total available water to a depth of $2.9 \mathrm{~m}$ for this soil at field capacity was approximately $400 \mathrm{~mm}$.
The date of $50 \%$ budbreak was determined by marking a single vine in each irrigation treatment replicate using the $0.6 \mathrm{~m}$ cross-arm trellis $(n=8)$. Budbreak was assumed to have taken place once green tissue was observed through the bud scales. The buds on all canes were observed every couple of days until no further buds developed. Subsequently, the dates when $50 \%$ of the buds that actually grew were back calculated based upon the total number of buds that initiated growth. Dates of anthesis and veraison were estimated visually. The date of $50 \%$ anthesis occurred when $50 \%$ of the calyptras (fused petals of the grape flower) were estimated to have fallen. Veraison occurred when the berries began to soften.

Entire grapevines were harvested at various times throughout the course of the study for the 0.2, 0.6, 1.0 and 1.4 irrigation treatments. The vines used were border vines separating the different trellises within a given irrigation treatment plot. Shoots were removed from the vines, taken to the lab and separated into leaves, stems (main axis of the shoot) and clusters. Fresh weights of the different organs were measured and then sub-sampled. Area of the subsampled leaves was determined with an area meter (LiCor, model 3100 area meter) prior to drying. Leaf area of the entire vine was calculated using the leaf area per dry weight ratio for each vine.

Shoot length was measured on numerous occasions during the 1991, 1992 and 1993 growing seasons. Twenty shoots were marked early in the growing season for each irrigation treatment using the vines within the $0.6 \mathrm{~m}$ crossarm trellis sub-plot (five shoots per plot in four of the blocks). If the shoots were cut due to hedging (a normal cultural practice to allow machinery continued access to travel between rows) shoot length included any growth arising from the uppermost lateral shoot. Trunk diameter was measured on each data vine within an irrigation/trellis subplot and the mean calculated. The mean of each trellis within an irrigation treatment plot was then used to calculate an irrigation treatment mean $(n=24)$. The measurements were taken just above the wire supporting the drip tubing on each trunk ( $0.4 \mathrm{~m}$ above the soil surface). Pruning weights were measured during the dormant portion of the growing season. The weight of the four middle vines of each trellis sub-plot within an irrigation treatment plot was used for data analysis $(n=8)$.

Water potential measurements were conducted according to the procedures of Williams and Araujo (2002). Predawn $\Psi\left(\Psi_{\mathrm{PD}}\right)$ measurements began at $\approx 0330 \mathrm{~h}$ and were finished prior to sunrise using a pressure chamber (Model 1000, PMS Instrument Co., Corvallis, OR, USA). Midday measurements of leaf water potential $\left(\Psi_{1}\right)$ generally were taken between 1230 and $1330 \mathrm{~h}$ Pacific Daylight Time. Leaf blades for $\Psi_{\mathrm{PD}}$ and $\Psi_{1}$ determinations were covered with a plastic bag, quickly sealed, and petioles then cut 
within 1-2 s. The time between leaf excision and chamber pressurization was generally $<10-15$ s. Leaves, chosen for $\Psi_{\mathrm{PD}}$ and $\Psi_{1}$ were fully expanded and mature. Pre-dawn $\Psi_{1}$ was measured only once in 1991, just prior to harvest, and more frequently in 1992 and 1993. For midday and diurnal $\Psi_{1}$ measurements, leaves exposed to direct solar radiation were used. A single leaf from a minimum of five individual vine replicates were measured and used for data analysis. Measurements of $\Psi_{1}$ and $\Psi_{\mathrm{PD}}$ were made in three (same blocks that SWC was measured) of the eight irrigation blocks. Environmental and reference ET $\left(\mathrm{ET}_{\mathrm{o}}\right)$ data were obtained from a California Irrigation Management Information System (CIMIS) weather station (\# 39) located $2 \mathrm{~km}$ from the vineyard site.

Data were analyzed via regression analyses using linear, quadratic, and cubic terms. Regressions with the best fit are presented. The relationships among water status measurements ( $\Psi_{1}$ and/or $\Psi_{\mathrm{PD}}$ ) were analyzed using the means of an individual irrigation treatment for a particular date or period of vine growth. Vegetative and reproductive growth were analyzed using analysis of variance for either irrigation or trellis treatments and means separated using Duncan's multiple range test. Differences were considered significant at $P \leq 0.05$.

\section{Results}

Budbreak took place between March 11 and 19 across years for the vines irrigated at the 1.0 irrigation amount treatment (Table 1). Irrigation treatment significantly affected the date of budbreak with the earliest budbreak generally occurring for the vines that were deficit irrigated the previous year (Fig. 1, unpublished data). Ten days separated the date of $50 \%$ budbreak for the 0 and 0.2 irrigated treatments compared to the vines irrigated at 1.0 $\mathrm{ET}_{\mathrm{c}}$ and greater in 1992. The next greatest difference occurred in 1991 when $50 \%$ budbreak of the 0.2-irrigation treatment occurred 7 days before that of the 1.4-irrigation treatment. Similar comparisons for dates of anthesis and veraison were not attempted due to difficulty in quantifying those two phenological stages. In general it was observed that anthesis occurred a little earlier for the deficit irrigated vines than those receiving applied water amounts greater than $\mathrm{ET}_{\mathrm{c}}$.

Irrigation of the vineyard did not commence until the last week of April to first week of May (Table 2). Midday $\Psi_{1}$ ranged from -0.6 to $-0.8 \mathrm{MPa}$ for the 1.0 irrigation treatment, except in 1992 when it approached -1.0 MPa. Applied water amounts to the 1.0 irrigation treatment from the first irrigation of the season to harvest ranged from 72 to $96 \%$ of measured $\mathrm{ET}_{\mathrm{c}}$ in 1990 and 1991, respectively. When averaged across years the $0.2,0.4,0.6,0.8,1.2$ and 1.4 irrigation treatments received approximately 22, 40, 60, 81,117 and $140 \%$ of the water applied to the 1.0 irrigation treatment, respectively. During years in which applied water to the 1.0 irrigation treatment was close to $\mathrm{ET}_{\mathrm{c}}$ measured with the lysimeter, SWC remained level once irrigations began (Fig. 2). The SWC of the 1.4 irrigation treatment increased while the SWC of the treatments being deficit irrigated decreased. When applied water amounts to the 1.0 treatment was $72-75 \%$ of $\mathrm{ET}_{\mathrm{c}}$ (1990 and 1992), SWC generally decreased as the season progressed for all treatments except the 1.4 treatment in 1992. Water was depleted in the soil profile for all treatments across all years from budbreak until harvest except for the 1.4 irrigation treatment in 1991, where there was a slight increase in SWC between those two dates (Table 3). Vine evapotranspiration for the 1.0 irrigation treatment (applied water [Table 2] plus water depleted in the soil profile [Table 3]) between budbreak and harvest was 574, 673, 638 and $829 \mathrm{~mm}$ in 1990, 1991, 1992 and 1993, respectively. These values compared favorably with water use measured with the weighing lysimeter during the same time frame (580, 661, 634 and $732 \mathrm{~mm}$ in 1990, 1991, 1992 and 1993, respectively).

The depletion of water in the soil profile was not necessarily related to applied water amounts. For example, $180 \mathrm{~mm}$ of water was depleted in the 0.6 irrigation treatment compared to $167 \mathrm{~mm}$ for the 0.2 treatment in 1990 while the depletion of water in the soil profile for the 1.0 irrigation treatment in 1992 was greater than those of all

Table 1 Phenological events of Thompson Seedless grapevines measured or estimated during the course of the growing season each year of the study

\begin{tabular}{lllll}
\hline Year & Date of budbreak & Date of anthesis & Date of veraison & Date of harvest \\
\hline 1990 & March 18 (77) & May 3 (123) & July 3 (184) & Sept. 24 (267) \\
1991 & March 19 (78) & May 23 (143) & July 8 (189) & Sept. 4 and 24 (247 and 267) \\
1992 & March 11 (71) & May 4 (125) & June 22 (174) & Sept. 3 (247) \\
1993 & March 12 (71) & May 9 (129) & July 2 (183) & Sept. 21 (264) \\
\hline
\end{tabular}

Data represent calculated dates of 50\% budbreak, approximate dates of anthesis and veraison for the 1.0 irrigation treatment and dates the fruit were harvested. Numbers following calendar dates in parentheses are days of year 


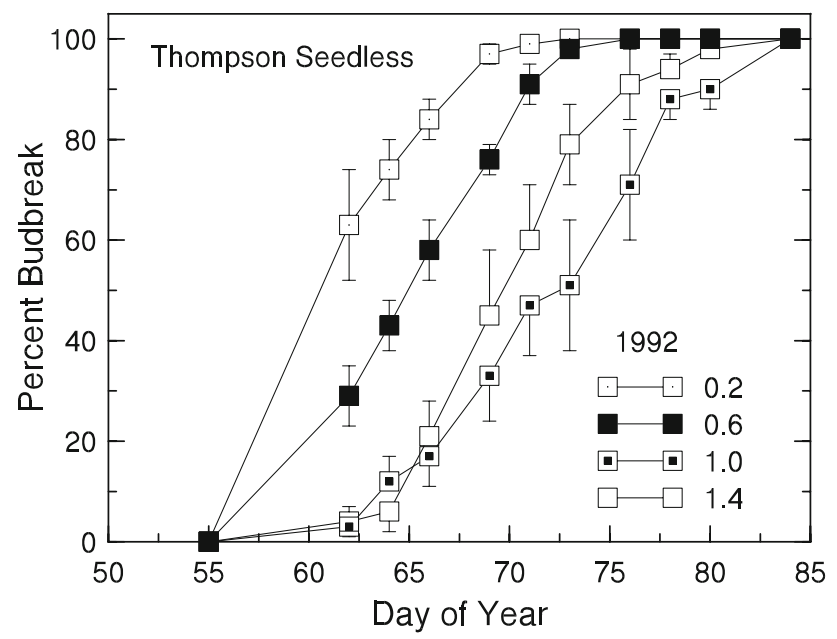

Fig. 1 The percent budbreak of Thompson Seedless grapevines measured in 1992 as a function of four irrigation treatments. The values on a particular date represent the percentage of the total buds that had broken on that date compared to the total number of buds that actually grew. Bars represent one SE. Values in which the SE bars do not overlap were in general significantly different from one another

other treatments. Soil water was depleted to a depth of $2.9 \mathrm{~m}$ and out to the middle of the row for the period from May to September in 1991 for both the 0.2 and 0.6 irrigation treatments (data not given). The SWC for the 0.6 irrigation treatment at the highest depth measured within the row in September was close to what is was in May. Conversely, SWC increased at all depths (albeit a small increase for some of the depths) and distances from the vine row for the 1.4 irrigation treatment. There was a small decrease with depth and distance from the row for the 1.0 irrigation treatment during the same time frame with an increase in SWC at the higher depths where access tubes were placed within the row directly beneath the drip lines.

There were significant differences in midday $\Psi_{1}$ prior to the application of water in 1991 (Fig. 3). Once irrigation commenced, midday $\Psi_{1}$ would continue to decrease for the
0 and 0.2 irrigation treatments across years, while midday $\Psi_{1}$ for the 0.6 treatment generally decreased in 1991 and 1992. Midday $\Psi_{1}$ for the 1.0 and 1.4 irrigation treatments remained above $-1.0 \mathrm{MPa}$ across all years as did those of the 0.6 irrigation treatment in 1993. The mean values of midday $\Psi_{1}$ for the specific irrigation treatments listed in Table 4 , as a function of various phenological stages, were generally significantly different from one another. The mean values of all $\Psi_{1}$ measurements in each irrigation treatment taken all season long were very similar to the anthesis to harvest values. The values from 1993, across all irrigation treatments, were higher than for similar intervals in 1991 and 1992. All values of midday $\Psi_{1}$, across irrigation treatments, within a particular interval (from one phenological stage to another) were linearly correlated ( $r$ values greater than 0.91 with correlations significant at the 0.001 level) with one another (data not given). In addition, the values of midday $\Psi_{1}$ and $\Psi_{\mathrm{PD}}$ measured on the last date prior to harvest were also highly correlated with midday $\Psi_{1}$ and $\Psi_{\mathrm{PD}}$ (using $\Psi_{\mathrm{PD}}$ data from 1992 and 1993) measured on other dates. Values of $\Psi_{\mathrm{PD}}$ for the 1.0 and 1.4 irrigation treatments prior to harvest across years ranged from -0.07 to $-0.1 \mathrm{MPa}$ while those of the non-irrigated treatment ranged from -0.5 to $-0.8 \mathrm{MPa}$.

There were significant $(P<0.05)$ differences in shoot length on the first measurement date in 1991 (Fig. 4). Shoot growth of the 0 and 0.2 irrigation treatments had stopped by that date and midday $\Psi_{1}$ of the 0.2 irrigation treatment was $-1.12 \mathrm{MPa}$ compared to values between -0.71 and -0.84 for the other three treatments. Clusters on the vines of the 0 and 0.2 irrigation treatments abscised during this period in 1991. Subsequently, shoot lengths of vines in the 0.2 and 0.6 irrigation treatments were significantly different from one another and from the 1.0 and 1.4 irrigation treatments. Shoot lengths were similar between the 0.2 and 0.6 irrigation treatments on all dates in 1992 as were lengths between the 1.0 and 1.4 irrigation treatments. Significant differences arose between the lower two

Table 2 Seasonal $\mathrm{ET}_{\mathrm{c}}$ (budbreak to October 31), date of first irrigation, $\mathrm{ET}_{\mathrm{c}}$ between the first irrigation of the season and harvest and applied water amounts between the first irrigation and harvest for 7 of the 8 irrigation treatments for each year of the study

\begin{tabular}{|c|c|c|c|c|c|c|c|c|c|c|}
\hline \multirow[t]{2}{*}{ Year } & \multirow{2}{*}{$\begin{array}{l}\text { Seasonal } \\
\mathrm{ET}_{\mathrm{c}} \\
(\mathrm{mm})\end{array}$} & \multirow{2}{*}{$\begin{array}{l}\text { Date of } \\
1 \text { st irr. }\end{array}$} & \multirow{2}{*}{$\begin{array}{l}\text { ET }_{\mathrm{c}}: 1 \mathrm{st} \text { irr. } \\
\text { To harvest } \\
(\mathrm{mm})^{\mathrm{a}}\end{array}$} & \multicolumn{7}{|c|}{ Irrigation treatments (applied water amounts at various fractions of lysimeter water use) } \\
\hline & & & & $\begin{array}{l}0.2 \\
(\mathrm{~mm})^{\mathrm{a}}\end{array}$ & 0.4 & 0.6 & 0.8 & 1.0 & 1.2 & 1.4 \\
\hline 1990 & 718 & Apr 27 & 580 & 99 & 168 & 237 & 327 & 416 & 489 & 556 \\
\hline 1991 & 865 & May 8 & 661 & 134 & 260 & 383 & 520 & 632 & 694 & 884 \\
\hline 1992 & 811 & May 8 & 634 & 112 & 186 & 304 & 371 & 477 & 558 & 663 \\
\hline 1993 & 857 & May 3 & 732 & 149 & 269 & 432 & 561 & 698 & 864 & 1002 \\
\hline
\end{tabular}

${ }^{a}$ Surface area per vine was $7.55 \mathrm{~m}^{2}$

The eighth treatment received no applied water except in 1991 at which time it was irrigated at the 0.2 amount throughout the season. $\mathrm{ET}_{\mathrm{c}}$ was determined with the weighing lysimeter. Irrigation to the vineyard was terminated on 30 August 1993, and resumed after harvest 


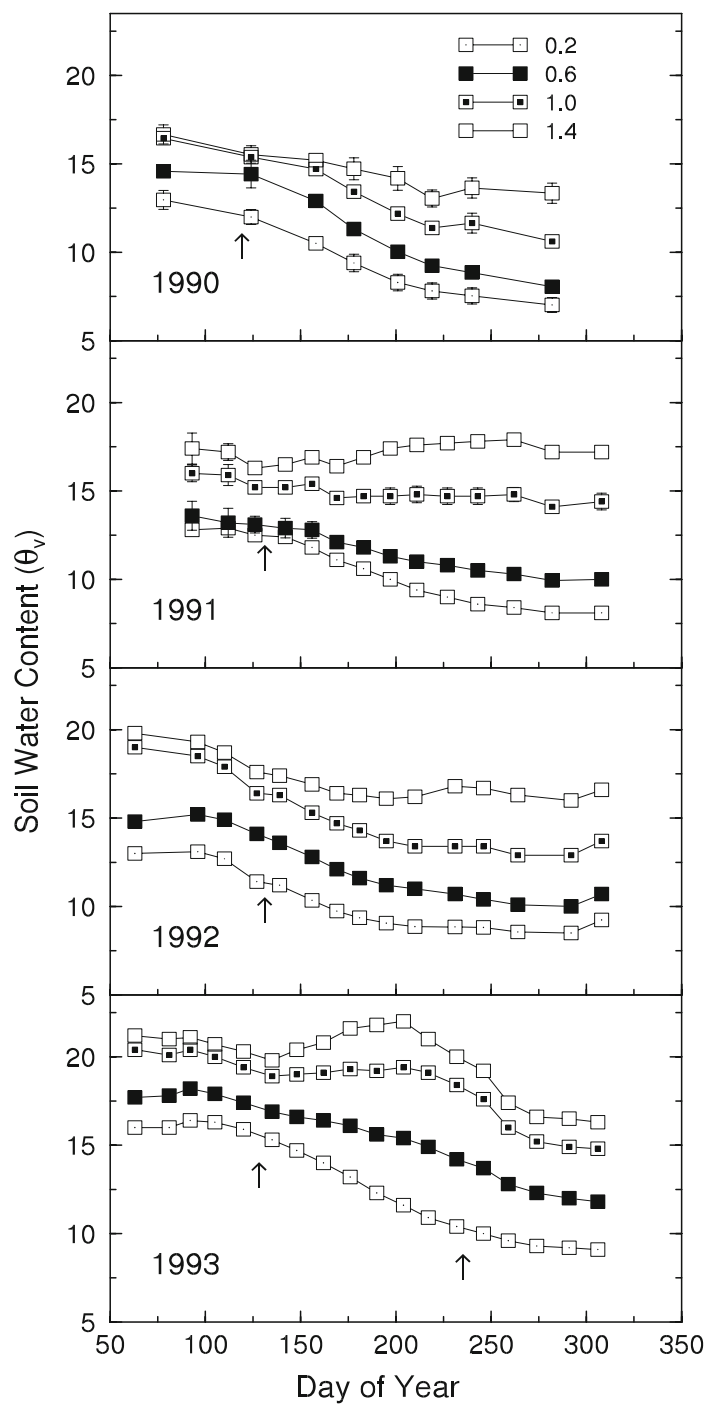

Fig. 2 Soil water content measured in four of the irrigation treatments used in the study from 1990 to 1993. Values are the means of all access tubes per site $(n=3)$. Bars, when larger than the symbol, represent one SE. The arrows denote the approximate date when irrigation commenced each year. The second arrow in 1993 denotes irrigation cutoff before harvest

irrigation treatments and the higher two treatments when midday $\Psi_{1}$ values were -1.16 and $-0.97 \mathrm{MPa}$, respectively. During the 1993 growing season, from DOY 125 onwards, shoot length of the 0.2 irrigation treatment was significantly less than shoot lengths of the other treatments. Midday $\Psi_{1}$ on DOY 138 for the $0.2,0.6$ and 1.0 treatments were $-0.82,-0.70$ and $-0.63 \mathrm{MPa}$, respectively.

As applied water increased, leaf area per vine also increased (Table 5). Leaf area of vines irrigated at the 1.0 and 1.4 levels were 2.8 and 3.3 greater, respectively, than the leaf area of vines irrigated at the 0.2 applied water amount in August of 1991. Subsequent to the 5th June sample date in 1992, leaf area per vine decreased for both the 0.2 and 0.6 irrigation treatments. The decreases in leaf
Table 3 The amount of water $(\mathrm{mm})^{\mathrm{a}}$ depleted in the soil profile from budbreak until harvest for the $0.2,0.6,1.0$ and 1.4 irrigation treatments across 4 years of the study

\begin{tabular}{llrrr}
\hline Year & \multicolumn{4}{l}{ Irrigation treatments } \\
\cline { 2 - 5 } & 0.2 & 0.6 & 1.0 & 1.4 \\
\hline 1990 & 167 & 180 & 158 & 93 \\
1991 & 132 & 97 & 41 & +15 \\
1992 & 132 & 101 & 161 & 95 \\
1993 & 190 & 150 & 131 & 117 \\
\hline
\end{tabular}

a Surface area per vine was $7.55 \mathrm{~m}^{2}$

Soil water content was measured using nine access tubes positioned in one quarter of a single vine's soil volume down to a depth of $3 \mathrm{~m}$ $(n=3)$

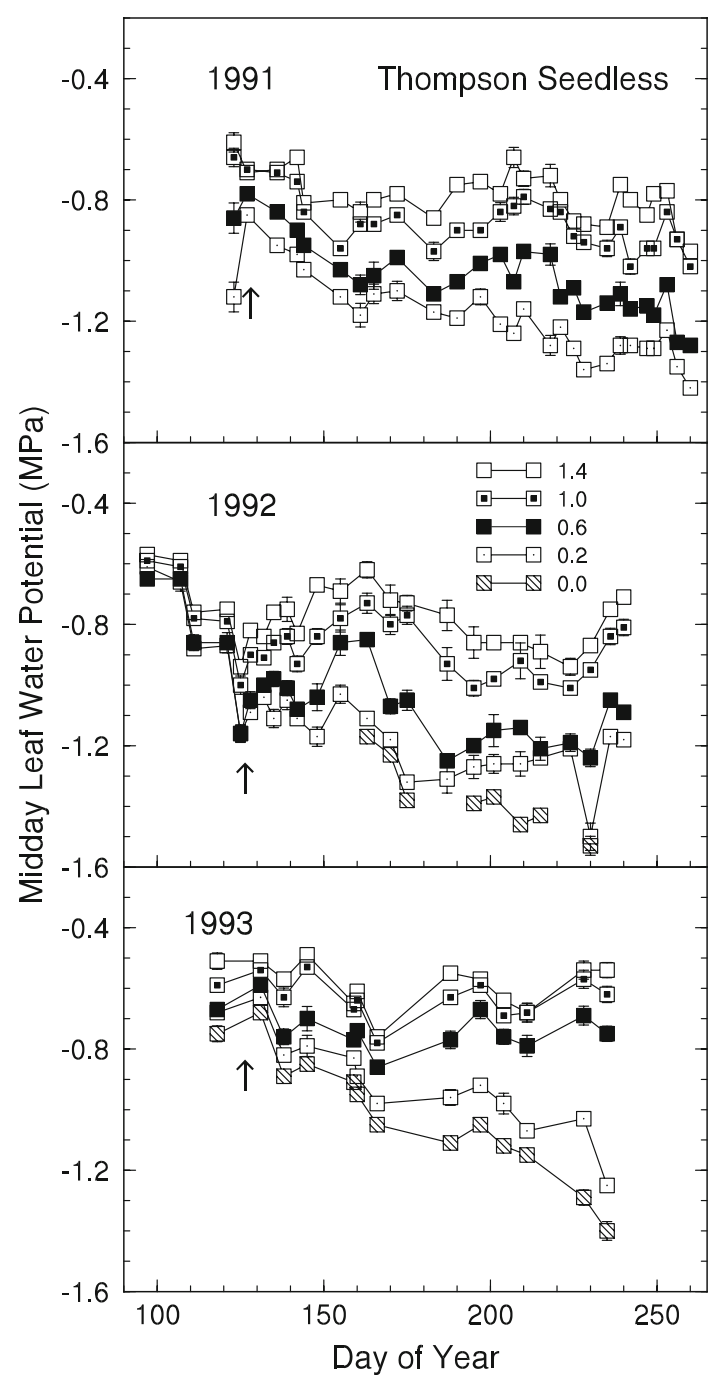

Fig. 3 Midday $\Psi_{1}$ measured throughout the 1991, 1992 and 1993 growing seasons as a function of irrigation treatment. Midday $\Psi_{1}$ of the 0 applied water treatment was not routinely measured until 1992 and 1993. Bars represent one SE and are shown when larger than the symbol. Arrows denote when irrigation commenced 
Table 4 The effect of year and irrigation treatment on mean midday leaf water potential $\left(\Psi_{1}\right)$ measured from anthesis to veraison, veraison to harvest and anthesis to harvest on Thompson Seedless grapevines

\begin{tabular}{|c|c|c|c|c|}
\hline Year $^{\mathrm{a}}$ & Irrigation treatment & $\begin{array}{l}\text { Anthesis to veraison } \\
\Psi_{1}(\mathrm{MPa})\end{array}$ & $\begin{array}{l}\text { Veraison to harvest } \\
\Psi_{1}(\mathrm{MPa})\end{array}$ & $\begin{array}{l}\text { Anthesis to harvest } \\
\Psi_{1}(\mathrm{MPa})\end{array}$ \\
\hline \multirow[t]{4}{*}{1991} & 0.2 & $-1.13 \pm 0.02$ & $-1.27 \pm 0.02$ & $-1.23 \pm 0.02$ \\
\hline & 0.6 & $-1.04 \pm 0.02$ & $-1.11 \pm 0.02$ & $-1.09 \pm 0.02$ \\
\hline & 1.0 & $-0.90 \pm 0.02$ & $-0.91 \pm 0.01$ & $-0.90 \pm 0.01$ \\
\hline & 1.4 & $-0.81 \pm 0.02$ & $-0.82 \pm 0.02$ & $-0.81 \pm 0.01$ \\
\hline \multirow[t]{5}{*}{1992} & 0.0 & $-1.26 \pm 0.06$ & $-1.44 \pm 0.03$ & $-1.37 \pm 0.04$ \\
\hline & 0.2 & $-1.10 \pm 0.03$ & $-1.27 \pm 0.13$ & $-1.17 \pm 0.03$ \\
\hline & 0.6 & $-0.98 \pm 0.03$ & $-1.17 \pm 0.02$ & $-1.06 \pm 0.03$ \\
\hline & 1.0 & $-0.85 \pm 0.02$ & $-0.95 \pm 0.03$ & $-0.89 \pm 0.02$ \\
\hline & 1.4 & $-0.76 \pm 0.03$ & $-0.83 \pm 0.02$ & $-0.79 \pm 0.02$ \\
\hline \multirow[t]{5}{*}{1993} & 0.0 & $-0.89 \pm 0.05$ & $-1.19 \pm 0.05$ & $-1.04 \pm 0.06$ \\
\hline & 0.2 & $-0.82 \pm 0.05$ & $-1.04 \pm 0.05$ & $-0.93 \pm 0.05$ \\
\hline & 0.6 & $-0.74 \pm 0.04$ & $-0.74 \pm 0.02$ & $-0.74 \pm 0.02$ \\
\hline & 1.0 & $-0.63 \pm 0.04$ & $-0.63 \pm 0.02$ & $-0.63 \pm 0.02$ \\
\hline & 1.4 & $-0.60 \pm 0.04$ & $-0.54 \pm 0.02$ & $-0.59 \pm 0.02$ \\
\hline
\end{tabular}

${ }^{a}$ The number of data points for the anthesis to veraison and veraison to harvest measurements were: $n=7$ and 10 in 1991,12 and 9 in 1992 and 6 and 6 in 1993, respectively. The number of data points for the anthesis to veraison and veraison to harvest for the 0.0 treatment in 1992 was 3 and 5 , respectively

Values represent the means $\pm \mathrm{SE}$

area per vine for the 0.2 and 0.6 treatments in 1992 and the 0.2 treatment in 1993 were due to leaf abscission. Any decrease in leaf area from one date to another in 1992 and 1993 for the 1.0 and 1.4 irrigation treatments were due to leaf area removed during mechanical shoot hedging.

Irrigation treatment had the greatest effect on pruning weights with little differences among trellis treatments with applied water amounts at less than full $\mathrm{ET}_{\mathrm{c}}$ (Fig. 5). At applied water amounts greater than full $\mathrm{ET}_{\mathrm{c}}$ there were significant differences among the trellis treatments, especially in 1992 and 1993. In those 2 years, pruning weights of the single wire trellis was significantly different from those of the 0.6 and $1.2 \mathrm{~m}$ cross-arm trellises. The increase in pruning weights from lower to higher applied water amounts was a result of an increase in lateral shoot production (L.E. Williams, personal observation) and increased stem diameter (data not given). Pruning weights were a linear function of applied water amounts for vines trained to the $0.6 \mathrm{~m}$ crossarm with $R^{2}$ values in excess of 0.95 (data not shown). Pruning weights were also a linear function of the seasonal mean midday $\Psi_{1}$ (Fig. 6). While there were no significant differences in the slopes of this relationship from 1 year to the next, the 1993 values of pruning weights at any irrigation treatment were similar to those from 1991 and 1992 at greater values of midday $\Psi_{1}$. Pruning weights as a function of $\Psi_{\mathrm{PD}}$ measured prior to harvest, decreased sharply with only minimal decreases in $\Psi_{\mathrm{PD}}$. Pruning weights were reduced by $70 \%$ at $\Psi_{\mathrm{PD}}$ values of $-0.2 \mathrm{MPa}$ compared to the irrigation treatments with $\Psi_{\mathrm{PD}}$ values at harvest of greater than $-0.1 \mathrm{MPa}$ under the conditions of this study.

There were significant differences in trunk diameter among the irrigation treatments at the end of the 1991 season (Table 6). Similar results were also found 2 years later. Trunk diameter measurements were also taken at various times during the 1991 and 1993 growing seasons. In general, there were similar increases in trunk diameter across all treatments from after budbreak until mid-season (early July). There was no increase or sometimes a decrease in trunk diameters for the $0-0.6$ irrigation treatments while the increase in diameter for the 0.8 treatment was less than the increase in trunk diameter for the 1.0-1.4 irrigation treatments from early July to the first of October. Trunk diameters of vines in all irrigation treatments decreased between October of 1991 and March 13th of 1992.

\section{Discussion}

The large number of irrigation treatments used in this study and the variability of climatic conditions across years allowed us to generate data providing a wide range of vine water statuses and enabled us to draw conclusions concerning how these treatments affected vegetative growth of Thompson Seedless grapevines and relate these changes to 


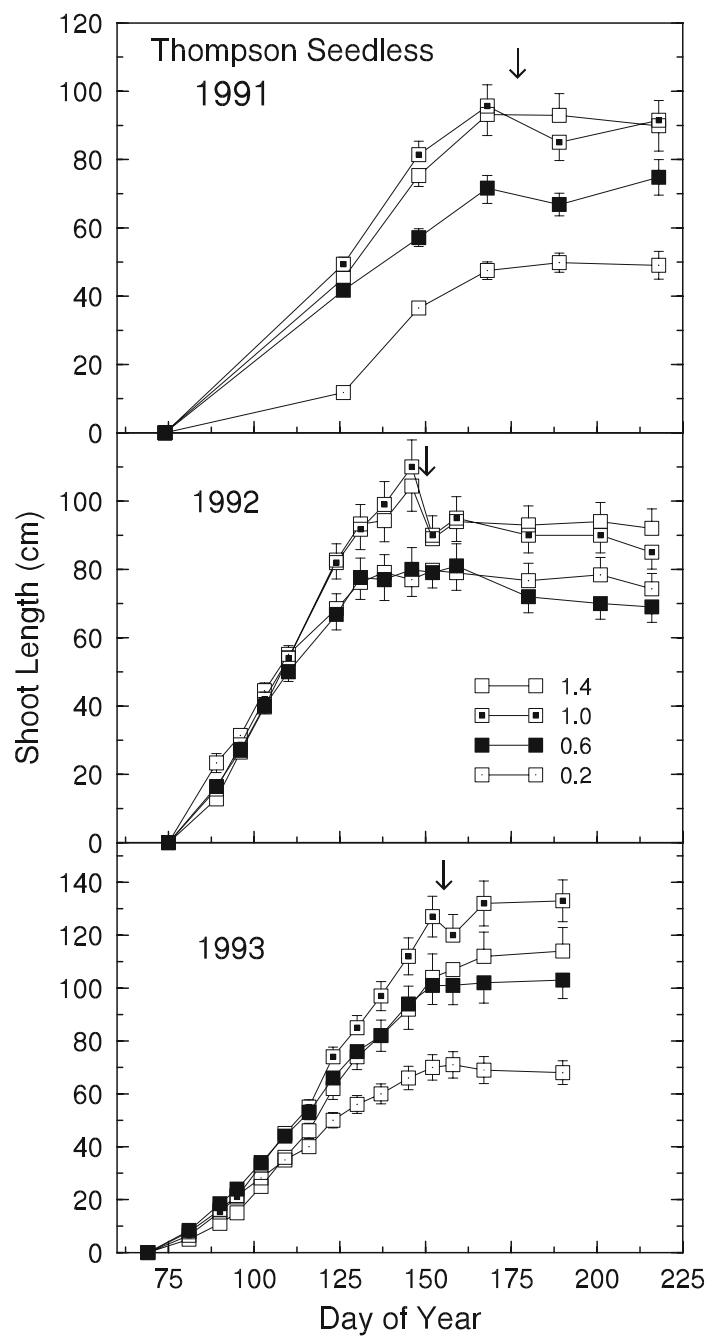

Fig. 4 The seasonal progression of shoot length measured in four of the irrigation treatments from 1991 to 1993 . The bars represent one SE and are shown when larger than the symbol. The arrows at the top of each graph represent the approximate dates the vines were first mechanically hedged different measures of vine water status. The no applied water and applied water at 0.2 and 0.4 of $\mathrm{ET}_{\mathrm{c}}$ treatments were included for comparison purposes only and would probably never be used in a commercial Thompson Seedless vineyard in the San Joaquin Valley.

Irrigation treatments in this study were set up as a linesource in each experimental block of the vineyard without using border rows between treatments. This was possible as vines were irrigated at a high frequency (up to seven times daily at midseason across years), with a maximum of $16 \mathrm{~L}$ per vine per irrigation event for the 1.0 irrigation treatment (more or less for the other treatments) to minimize lateral water movement in the soil profile. Mean SWC decreased for the 0.2 and 0.6 irrigation treatments during the course of each growing season and their SWC values were significantly less than those of the 1.0 and 1.4 irrigation treatments. Deficit irrigating vines with applied water amounts at 0.2 and 0.6 of $\mathrm{ET}_{\mathrm{c}}$ depleted water to a depth of $2.5 \mathrm{~m}$ and midway between rows from the first measurement of the season to harvest. It was also demonstrated that SWC remained constant throughout the course of the season if the vines were irrigated at $100 \%$ of $\mathrm{ET}_{\mathrm{c}}$ while it increased if they were irrigated at $140 \%$ of $\mathrm{ET}_{\mathrm{c}}$. It is interesting to point out that SWC for the vines that had been deficit irrigated the previous year was always lower than the SWC for vines irrigated at $\mathrm{ET}_{\mathrm{c}}$ or greater. This even occurred when rainfall was in excess of $350 \mathrm{~mm}$ during the dormant portion of the growing season from 1992 to 1993 (Williams et al. 2003b). The above information should be helpful in future studies where SWC is monitored and conclusions drawn concerning whether applied water amounts were close to estimated ET $_{\mathrm{c}}$.

The daily and mean values of midday $\Psi_{1}$ for the 1.0 and 1.4 irrigation treatments reported herein are generally greater than those previously reported for vines that were

Table 5 Leaf area $\left(\mathrm{m}^{2}\right.$ vine $\left.{ }^{-1}\right)$ of Thompson Seedless grapevines measured as a function of year and date during the growing season and irrigation treatment

\begin{tabular}{|c|c|c|c|c|c|}
\hline \multirow[t]{2}{*}{ Year } & \multirow[t]{2}{*}{ Date (DOY) } & \multicolumn{4}{|c|}{ Irrigation treatment } \\
\hline & & 0.2 & 0.6 & 1.0 & 1.4 \\
\hline 1991 & Aug. 13 (225) & $11.4 \pm 1.4$ & $22.8 \pm 3.4$ & $31.7 \pm 2.1$ & $38.0 \pm 3.9$ \\
\hline \multirow[t]{5}{*}{1992} & May 4 (125) & $11.9 \pm 0.4$ & $13.7 \pm 0.7$ & $18.1 \pm 0.9$ & $15.6 \pm 1.5$ \\
\hline & Jun. 5 (157) & $14.6 \pm 1.1$ & $19.1 \pm 0.8$ & $27.0 \pm 2.7$ & $30.5 \pm 2.9$ \\
\hline & Jul. 8 (189) & $11.3 \pm 1.2$ & $17.9 \pm 2.6$ & $24.5 \pm 1.9$ & $27.2 \pm 2.1$ \\
\hline & Aug. 12 (224) & $8.4 \pm 0.1$ & $15.2 \pm 0.4$ & $23.7 \pm 1.1$ & $32.6 \pm 1.3$ \\
\hline & Sep. 7 (250) & $8.2 \pm 0.1$ & $16.8 \pm 0.6$ & $23.3 \pm 1.4$ & $25.5 \pm 1.4$ \\
\hline \multirow[t]{4}{*}{1993} & May 18 (128) & $16.9 \pm 0.7$ & $17.2 \pm 2.0$ & $17.7 \pm 1.3$ & $18.9 \pm 1.1$ \\
\hline & Jun. 23 (143) & $19.9 \pm 1.6$ & $26.8 \pm 2.4$ & $30.6 \pm 2.6$ & $36.6 \pm 1.9$ \\
\hline & Jul. 19 (200) & $19.8 \pm 3.9$ & $26.5 \pm 2.8$ & $32.9 \pm 2.1$ & $33.0 \pm 3.4$ \\
\hline & Sep. 4 (247) & $14.3 \pm 2.3$ & $25.5 \pm 2.4$ & $34.1 \pm 3.0$ & $37.0 \pm 3.8$ \\
\hline
\end{tabular}

Values represent the means of three individual vines $\pm \mathrm{SE}$ 


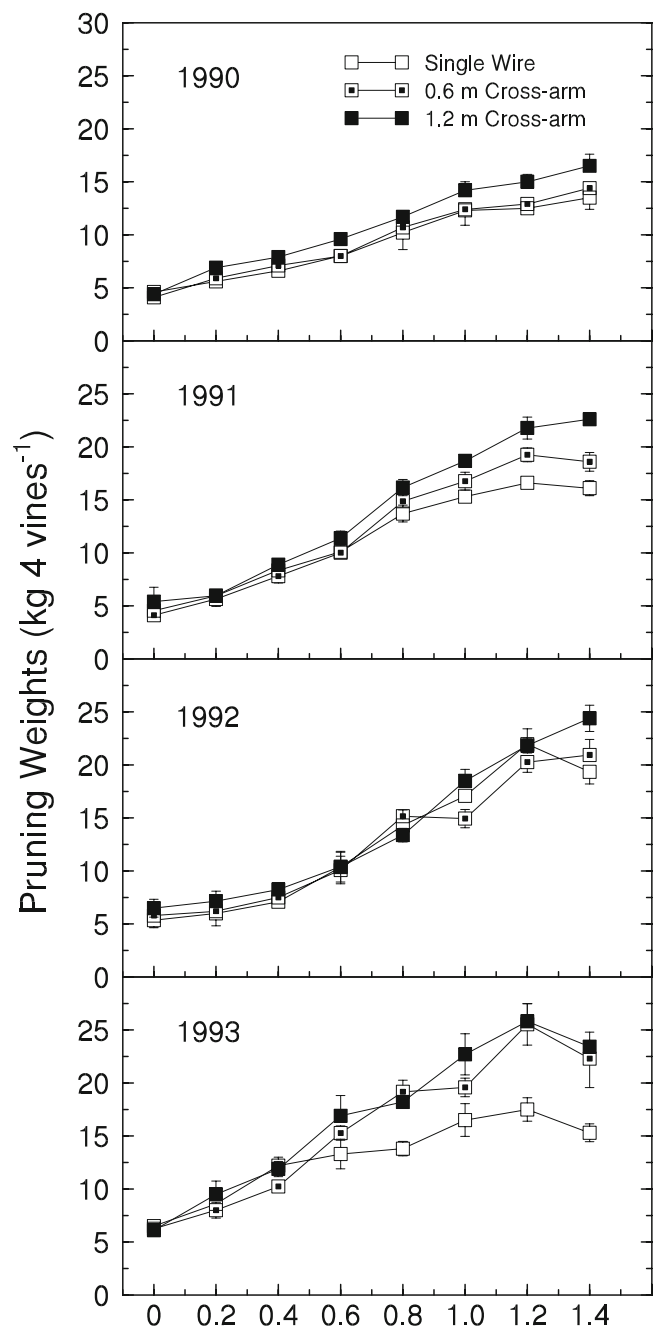

Applied Water (fraction of lysimeter water use)

Fig. 5 Pruning weights measured as a function of irrigation and trellis treatments across all years of the study. Other information is as given in previous figures

assumed to be well-watered (Correia et al. 1995), were the well-watered treatment vines under furrow irrigation (Smart 1974) or irrigated at $100 \%$ of estimated $\mathrm{ET}_{\mathrm{c}}$ (Salón et al. 2005). They are similar to midday $\Psi_{1}$ values reported by Grimes and Williams (1990) and Girona et al. (2006) for treatments irrigated at $100 \%$ of estimated $\mathrm{ET}_{\mathrm{c}}$ and van $\mathrm{Zyl}$ (1987) for vines in his wet treatment (10\% allowable soil water depletion). The lowest value of midday $\Psi_{1}$ measured in this study $(\sim-1.5 \mathrm{MPa})$ was that for the no applied water and the 0.2 irrigation treatments close to harvest in 1992. It would appear that a $\Psi_{\mathrm{PD}}$ value $>-0.1 \mathrm{MPa}$ indicates that the vines were not stressed for water under the conditions of this study. This value is greater than the $\Psi_{\mathrm{PD}}$ value ( $\geq-0.2 \mathrm{MPa}$ ) often assumed to indicate the absence of or only minimal water stress (Deloire et al. 2004). The lowest $\Psi_{\mathrm{PD}}$ value measured for the 0.2 irrigation treatment in this study was $-0.22 \mathrm{MPa}$, only because irrigation was
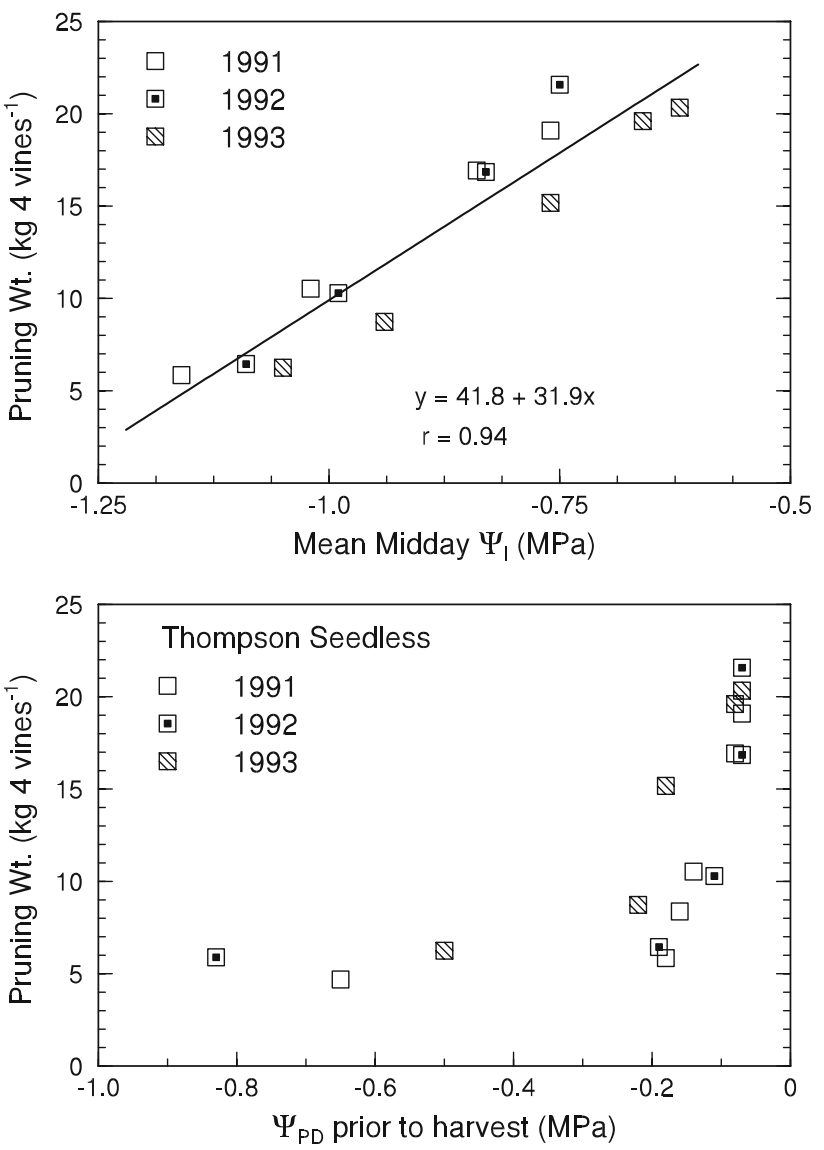

Fig. 6 Pruning weights as a function of mean midday $\Psi_{1}$ measured throughout the growing season and $\Psi_{\mathrm{PD}}$ measured prior to harvest for 3 years of the study. Pruning weights were taken from the $0.6 \mathrm{~m}$ trellis in each of the irrigation treatments

cut off prior to harvest, otherwise it was generally $>$ $-0.2 \mathrm{MPa}$.

Deficit irrigation of grapevines in this study generally advanced the date of budbreak compared to vines irrigated at $\mathrm{ET}_{\mathrm{c}}$ or greater. Year did affect the absolute number of days separating the treatments. A review of the literature did not find comparable data published elsewhere. Thompson Seedless grapevines are cane pruned unlike many of the other cultivars of $V$. vinifera that are spur pruned. It is unknown whether this may explain the results reported here. In addition, a difference of a week to 10 days in the date of budbreak would not result in comparable difference in dates of anthesis and/or veraison as found in this study and elsewhere (Williams 1987).

As expected, the increase in and final shoot length was significantly affected by irrigation treatment. Shoot length increased almost linearly for vines that were irrigated at $\mathrm{ET}_{\mathrm{c}}$ or greater up until the time the vines were hedged. There were several anomalies regarding shoot length across years. Shoots on vines in the 0.2 treatment in 1991 initiated growth but then shoot growth stopped for a while. 
Table 6 Trunk diameter of Thompson Seedless grapevines as a function of irrigation treatment measured at the end of the 1991 and 1993 growing seasons and the change in diameter over the 2-year period

\begin{tabular}{llll}
\hline Irrigation treatment & \multicolumn{2}{l}{ Trunk diameter } & $\begin{array}{l}\text { Change in } \\
\text { diameter }(\mathrm{cm})\end{array}$ \\
\cline { 2 - 3 } & $\begin{array}{l}30 \text { September } \\
1991(\mathrm{~cm})\end{array}$ & $\begin{array}{l}\text { 8 October } \\
1993(\mathrm{~cm})\end{array}$ \\
\hline 0 & $4.29 \mathrm{f}$ & $4.99 \mathrm{e}$ & 0.70 \\
0.2 & $4.41 \mathrm{e}$ & $5.04 \mathrm{e}$ & 0.63 \\
0.4 & $4.63 \mathrm{~d}$ & $5.27 \mathrm{~d}$ & 0.64 \\
0.6 & $4.77 \mathrm{c}$ & $5.50 \mathrm{c}$ & 0.73 \\
0.8 & $5.03 \mathrm{~b}$ & $5.79 \mathrm{~b}$ & 0.76 \\
1.0 & $5.12 \mathrm{ab}$ & $6.01 \mathrm{a}$ & 0.89 \\
1.2 & $5.15 \mathrm{ab}$ & $6.02 \mathrm{a}$ & 0.87 \\
1.4 & $5.22 \mathrm{a}$ & $6.15 \mathrm{a}$ & 0.93 \\
\hline
\end{tabular}

Means followed by a different letter within a column are significantly different at the $P<0.05$ level. $(n=24)$

At this time, irrigation had not commenced and midday $\Psi_{1}$ was close to $-1.2 \mathrm{MPa}$ for that treatment. The increase in shoot length of the 1.4 irrigation treatment lagged behind that of shoots in the 1.0 irrigation treatment subsequent to DOY 125 in 1993 and remained such throughout the remainder of the year. Lastly, prior to DOY 125 in 1993 shoot lengths of the 0.2 irrigation treatment were significantly less than those of the 1.0 irrigation treatment despite the fact that midday $\Psi_{1}$ at that time was approximately $-0.7 \mathrm{MPa}$. The above indicates that over irrigation of Thompson Seedless grapevines can negatively affect shoot growth. In addition, the reduction in shoot growth for the 0.2 , deficit irrigated vines can occur at $\Psi_{1}$ values greater than often assumed to stop or slow shoot elongation rate. It has been demonstrated that there is a linear reduction in the growth rate of leaves and shoot apices when tissue $\Psi$ decreases from -0.4 to $-1.0 \mathrm{MPa}$ and that growth of leaves, internodes and tendrils can be reduced 100, 60 and $50 \%$ at a tissue $\Psi$ of $-1.0 \mathrm{MPa}$ with a complete inhibition of internode growth at a tissue $\Psi$ of $-1.2 \mathrm{MPa}$ (Schultz and Matthews 1988). Alternatively, it has been shown that non-hydraulic signals, perhaps originating in the roots (abscisic acid, ABA), may also be responsible for the inhibition of shoot growth (Dry and Loveys 1999; Dry et al. 2000). Such may be the cause in reducing shoot length for the 0.2 irrigation treatment in 1993 in this study.

The canopies of the vines used in this study were quite large even for vines in the 0.2 irrigation treatment. Leaf areas for the vines in the 1.0 and 1.4 irrigation treatments were close to or often exceeded $30 \mathrm{~m}^{2}$ vine $^{-1}$ and the leaf areas for the vines in 0.6 irrigation treatment were in excess of $25 \mathrm{~m}^{2}$ vine $^{-1}$ during the 1993 growing season. The great amount of leaf area for the deficit, irrigated vines may have been due to the high frequency with which the vines were irrigated. The reduction in leaf area for vines in the 0.2 irrigation treatment from mid-season onwards was due to leaf abscission, despite the availability of irrigation water daily and throughout the growing season. Canopy size or leaf area per unit row length has important implications for next year's bud fruitfulness in grapevines, especially Thompson Seedless. It has been demonstrated that shading compound buds of Thompson Seedless (syn. Sultana) reduced cluster primordia formation (May 1965). Indeed, the numbers of clusters per vine were reduced as applied water increased, especially those vines irrigated at $\mathrm{ET}_{\mathrm{c}}$ or greater (Williams et al. 2009).

Pruning weights (a measure of vegetative growth) were a linear function of applied water amounts and seasonal, mean midday $\Psi_{1}$ in this study for vines trained to the $0.6 \mathrm{~m}$ cross-arm trellis. These results indicate that vegetative growth was highly sensitive to vine water status in this study despite results given previously concerning a possible lack of a relationship between hydraulic signals and shoot length. This may be due to the fact that radial shoot growth is less affected by water deficits than apical shoot growth (Matthews et al. 1987; Williams and Matthews 1990).

Trunk growth is affected by water deficits in grapevines (Intrigliolo and Castel 2007; Myburg 1996; Sellés et al. 2004; van Zyl 1984). Trunk diameter decreased significantly for the sustained deficit irrigated treatments compared to those irrigated at $\mathrm{ET}_{\mathrm{c}}$ or greater in this study. Trunk diameter did not increase further with the application of water at amounts greater than $\mathrm{ET}_{\mathrm{c}}$. The increase in trunk diameter averaged $4.5 \mathrm{~mm}$ per year for the 1.0 , 1.2 and 1.4 irrigation treatments while the increase averaged $3.3 \mathrm{~mm}$ per year for the no applied water, 0.2 and 0.4 irrigation treatments. It is interesting to note that maximum daily water use during the 1993 growing season was almost $50 \mathrm{~L} \mathrm{~d}^{-1}$ with maximum hourly water use greater than $7.1 \mathrm{~L}$ (Williams et al. 2003b). If the trunk diameter of the vines in the lysimeter were similar to those reported in Table 6 for October $1993(\sim 6.0 \mathrm{~cm})$, then the cross-sectional area of the vines in the lysimeter would be $28.4 \mathrm{~cm}^{2}$. The velocity of sap through the trunk using the previously given data, assuming the entire cross-sectional area was active in the transport of water, would be $250 \mathrm{~cm}$ per hour.

\section{Conclusions}

This study is the first the authors are aware in which irrigation treatments consisted of applied water amounts at various fractions of measured $\mathrm{ET}_{\mathrm{c}}$ by grapevines grown in a weighing lysimeter. In addition, the various treatments were irrigated when the vines within the lysimeter were 
irrigated (whenever they used $2 \mathrm{~mm}$ of water), albeit at their respective fraction. The treatments provided a wide array of SWC and vine water statuses. Midday $\Psi_{1}$ of vines irrigated at $\mathrm{ET}_{\mathrm{c}}$ or greater was rarely lower than $-0.9 \mathrm{MPa}$ throughout the growing season while $\Psi_{\mathrm{PD}}$ was always greater than $-0.1 \mathrm{MPa}$. Sustained deficit irrigation significantly reduced leaf area per vine and pruning weights compared to those irrigated at $\mathrm{ET}_{\mathrm{c}}$ or greater. Pruning weights were a linear function of both applied water amounts and seasonal, mean midday $\Psi_{1}$. Shoot growth was adversely affected by the application of water in amounts greater than $\mathrm{ET}_{\mathrm{c}}$, in some years and as a function of trellis system. The results indicate that either measurements of soil or plant water status could be used to determine when to begin irrigating each year. Subsequently, water amounts at a specific fraction of estimated vineyard $\mathrm{ET}_{\mathrm{c}}$ could be applied to obtain a desirable canopy and conserve water.

Acknowledgments We thank Peter Biscay, Weigang Yang, Nona Ebisuda and Paul Wiley for their technical assistance and R. M. Mead and D. A. Clark for their assistance with the weighing lysimeter. We also thank Dr. A. Patakas for his editorial comments. The research was funded in part by grants from the American Vineyard Foundation and the California Raisin Advisory Board to L. E. Williams. Mention of trade names or proprietary products is for the convenience of the reader only and does not constitute endorsement or preferential treatment by the University of California or USDA/ARS.

Open Access This article is distributed under the terms of the Creative Commons Attribution Noncommercial License which permits any noncommercial use, distribution, and reproduction in any medium, provided the original author(s) and source are credited.

\section{References}

Allen RA, Pereira LS, Raes D, Smith M (1998) Crop evapotranspiration: guidelines for computing crop water requirements. (FAO irrigation and drainage paper 56) FAO, Rome

Araujo F, Williams LE, Grimes DW, Matthews MA (1995) A comparative study of young 'Thompson Seedless' grapevines under drip and furrow irrigation. I. Root and soil water distributions. Sci Hortic 60:235-249

Ayars JE, Johnson RS, Phene CJ, Trout TJ, Clark DA, Mead RM (2003) Water use by drip irrigated late season peaches. Irrig Sci 22:187-194

Correia MJ, Pereira JS, Chaves MM, Rodrigues ML, Pacheco CA (1995) ABA xylem concentrations determine maximum daily leaf conductance of field-grown Vitis vinifera L. plants. Plant Cell Environ 18:511-521

Daane KM, Williams LE (2003) Manipulating vineyard irrigation amounts to reduce insect pest damage. Ecol Appl 13:1650-1666

Deloire A, Carbonneau A, Wang Z, Ojeda H (2004) La vigne et l'eau. J Int Sci Vigne Vin 38:1-13

Dry PR, Loveys BR (1999) Grapevine shoot growth and stomatal conductance are reduced when part of the root system is dried. Vitis 38:151-156

Dry PR, Loveys BR, Düring H (2000) Partial drying of the rootzone of grape. I. Transient changes in shoot growth and gas exchange. Vitis 39:3-7
Fereres E, Evans RG (2006) Irrigation of fruit trees and vines: an introduction. Irrig Sci 24:55-57

Fereres E, Soriano MA (2007) Deficit irrigation for reducing agricultural water use. J Exp Bot 58:147-159

Girona J, Mata M, Del Campo J, Arbonés A, Bartra E, Marsal J (2006) The use of midday leaf water potential for scheduling deficit irrigation in vineyards. Irrig Sci 24:115-127

Grimes DW, Williams LE (1990) Irrigation effects on plant water relations and productivity of 'Thompson Seedless' grapevines. Crop Sci 30:255-260

Hsiao TC, Steduto P, Fereres E (2007) A systematic and quantitative approach to improve water use efficiency in agriculture. Irrig Sci 25:209-231

Intrigliolo DS, Castel JR (2007) Evaluation of grapevine water status from trunk diameter variations. Irrig Sci 26:49-59

Intrigliolo DS, Pérez D, Castel JR (2005) Water relations of field grown drip irrigated 'Tempranillo' grapevine. Acta Hortic 689:317-323

Jones HG (2004) Irrigation scheduling: advantages and pitfalls of plant-based methods. J Exp Bot 55:2427-2436

Laraus JL (2004) The problems of sustainable water use in the Mediterranean and research requirements for agriculture. Ann appl Biol 144:259-272

Matthews MA, Anderson MM, Schultz HR (1987) Phenologic and growth responses to early and late season water deficits in Cabernet Franc. Vitis 26:26-30

May P (1965) Reducing inflorescence formation by shading individual Sultana buds. Aust J Biol Sci 18:463-473

Morison JIL, Baker NR, Mullineaux MP, Davies WJ (2008) Improving water use in crop production. Philos Trans R Soc B 363:639-658

Myburg PA (1996) Response of Vitis vinifera L. cv. Barlinka/Ramsey to soil water depletion levels with particular references to trunk growth parameters. S Afr J Enol Vitic 17:3-14

Salón JL, Chirivella C, Castel JR (2005) Response of cv. Bobal to timing of deficit irrigation in Requena, Spain: Water relations, yield and wine quality. Am J Enol Vitic 56:1-8

Schultz HR, Matthews MA (1988) Vegetative growth distribution during water deficits in Vitis vinifera L. Aust J Plant Physiol 15:641-656

Sellés G, Ferreira R, Muñoz I, Silva H (2004) Physiological indicators of plant water status as criteria for irrigation scheduling in table grapes cv. Crimson Seedless, irrigated dry drip. Acta Hortic 664:599-605

Smart RE (1974) Aspects of water relations of the grapevine (Vitis vinifera). Am J Enol Vitic 25:84-91

Stevens RM, Harvey G, Aspinall D (1995) Grapevine growth of shoots and fruit linearly correlate with water stress indices based on root-weighted soil matric potential. Aust J Grape Wine Res 1:58-66

van Zyl JL (1984) Response of Colombar grapevines to irrigation as regards quality aspects and growth. S Afr J Enol Vitic 5:19-28

van Zyl JL (1987) Diurnal variation in grapevine water stress as a function of changing soil water status and meteorological conditions. S Afr J Enol Vitic 8:45-52

Williams LE (1987) The effect of cyanamide on budbreak and vine development of Thompson Seedless grapevines in the San Joaquin Valley of California. Vitis 26:107-113

Williams LE, Araujo F (2002) Correlations among predawn leaf, midday leaf, and midday stem water potential and their correlations with other measures of soil and plant water status in Vitis vinifera L. J Am Soc Hortic Sci 127:448-454

Williams LE, Ayars JE (2005a) Water use of Thompson Seedless grapevines as affected by the application of gibberellic acid (GA3) and trunk girdling-practices to increase berry size. Agric For Meteor 129:85-94 
Williams LE, Ayars JE (2005b) Grapevine water use and the crop coefficient are linear functions of the shaded area measured beneath the canopy. Agric For Meteor 132:201-211

Williams LE, Baeza P (2007) Relationships among ambient temperature and vapor pressure deficit and leaf and stem water potentials of fully irrigated, field-grown grapevines. Am J Enol Vitic 58:173-181

Williams LE, Matthews MA (1990) Grapevines. In: Stewart BA, Nielsen DR (eds) Agronomy monograph \#30 irrigation of agricultural crops. ASA-CSSA-SSSA Publishers, Madison, Wisconsin, pp 1019-1055

Williams LE, Trout TJ (2005) Relationships among vine and soil based measures of water status in a Thompson Seedless vineyard in response to high frequency drip irrigation. Am J Enol Vitic $56: 357-366$
Williams LE, Dokoozlian NK, Wample RL (1994) Grape. In: Shaffer B, Anderson PC (eds) Handbook of environmental physiology of fruit crops. Volume 1. Temperate crops. CRC Press, Orlando, Florida, pp 83-133

Williams LE, Phene CJ, Grimes DW, Trout TJ (2003a) Water use of young Thompson Seedless grapevines in California. Irrig Sci 22:1-9

Williams LE, Phene CJ, Grimes DW, Trout TJ (2003b) Water use of mature Thompson Seedless grapevines in California. Irrig Sci 22:11-18

Williams LE, Grimes DW, Phene CJ (2009) The effects of applied water amounts at various fractions of measured evapotranspiration on reproductive growth and water productivity of Thompson Seedless grapevines. Irrig Sci. doi:10.1007/s00271-009-0173-0 